\title{
Design Thinking Budget and Savings Planner Inspiration of the Hadith of the Prophet
}

\author{
Tryana Hafilda Dewi \\ Department of Religious Studies, Faculty of Ushuluddin \\ UIN Sunan Gunung Djati Bandung, Indonesia \\ tryana.filda@gmail.com
}

\begin{abstract}
This study aims to discuss the inspiration for the hadith of the Prophet. in financial management. Qualitative research methods through literature study and field studies with the hadith design approach. The results and discussion of this research include good management education, inspiration for the example of the Prophet. in saving, and the Budget and Saving Planner. This research concludes that the hadith of the Prophet. has inspirational messages in raising awareness of saving with the presence of the Budget and Savings Planner book through innovative ideas with continuous testing appropriately to create Indonesians who like to save and increase awareness of saving for the Indonesian people.

Keywords: Budget and Savings Planner, Design Thinking, Hadist
\end{abstract}

\section{Intruduction}

Early 2020, the world was shocked by the outbreak of an epidemic that originated in Wuhan, China. The Corona virus Plague (Covid-19) has infected almost all countries in the world (Buana, 2020). It seems that as a warning of medical needs, preparedness is also in various aspects, one of which is the economy (Shofiana, 2020). Indonesia's economic projection in 2020 of 5 percent will now be very difficult for Indonesia to achieve (Manggala, 2020). To overcome this problem, especially for students who have not earned an income, easy steps can be taken but have a big impact, one of which is by saving. However, it turns out that the awareness of saving in the community is still low (Meta Ardiana, 2016). Bank Indonesia (BI) noted that the minimum number of Indonesians has savings. The World Bank survey in 2010 states that $32 \%$ of Indonesia's population has no financial savings (savings), both in the formal and informal sectors and is included in the financially excluded category (Adriana, 2016). As stated by Keynes, that the rate of economic growth of a country depends on the ability to save, the higher the saving rate will encourage the level of investment and will increase economic growth (Keynes, 1935). Once the role is important, the habituation that needs to be instilled in children from 
childhood to adulthood, especially in the adolescent phase, where in adolescence students have begun to be given confidence in their finances independently.

Saving activity is a saving behavior so that finances (financially) can be managed properly. As found in the Quran Surat al-Isra verses 26-27, which means: "And do not waste (your wealth) wastefully. In fact, the extravagant is the brother of Satan and that satan is very dissent to his Rabb" (Quran). In his hadith, Rasulullah Saw. said "Save a part of your property for the good of your future, because it is much better for you" (H.R. Bukhari). Humans never know what will happen in the future, so it's best to prepare for the future. In another hadith, Rasulullah Saw. said: "Surely you leave your heirs in a rich state, it is better than you leave them in a poor state ..." (Narrated by Bukhari Muslim). Living well, let alone having property, is definitely everyone's dream. Especially if you can pass it on to your children and grandchildren and use it for alms. It turns out that saving activities are very beneficial for many parties (Delyana Rahmawany Pulungan, 2019).

Based on the explanation above, the writer tries to compile a research formula, namely the formulation of the problem, research questions, and research objectives (Darmalaksana, 2020a). The formulation of this problem is, comes from the inspiration of the hadith of the Prophet. in planting the character likes to save. The research question is, how to inspire the hadith of the Prophet. in cultivating character and morale so that he likes saving. The research objective is to discuss the inspiration for the hadith of the Prophet. in the implementation of saving character development. This study focuses on "Budget and Savings Planner" for more mature financial planning.

\section{Research Methods}

This research method is qualitative with literature study and field studies (Darmalaksana, 2020c). While the analysis in this study used a design thinking approach (Darmalaksana, 2019). The design thinking approach procedure (Darmalaksana, 2020d) is shown in figure 1.

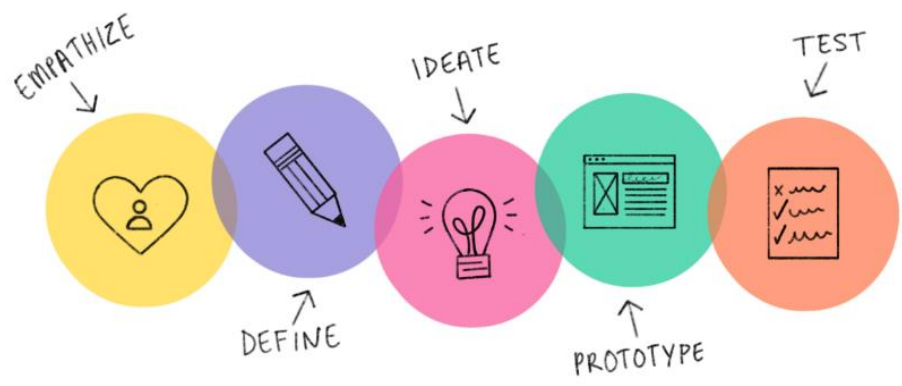

Figure 1 Design Thinking Procedure 
The design thinking procedure in figure 1 includes the empathize, define, ideate, prototype, and test phases (Henriksen et al., 2017).

1. The empathize phase (empathy) is used to understand the problem. Empathy is carried out through the process of observing, engaging through conversations, and in-depth interviews. The purpose of this phase is to understand the problem thoroughly (Darmalaksana, 2020; Steinke et al., 2018).

2. Phase define (define) the problem for clarity of the problem. Researchers apply the power of thinking to understanding problems. Once the problem is clearly understood, the researcher can move to the next stage to generate ideas for solving the problem. The definition phase ends with a clear definition of the scope of the problem (Darmalaksana, 2020; Steinke et al., 2018).

3. The ideate phase (generating ideas) for the solution to the previously defined problem. Researchers make it possible to use logic critically, creatively, and innovatively. The ideating phase includes a concept map, frame of mind, and prototype design. In particular, a prototype with a new view as a solution (Darmalaksana, 2020; Steinke et al., 2018).

4. The prototype phase (making a prototype) from a new innovation idea to a materialized product. The more realistic the prototype idea, the better it will be realized. It is possible for researchers to recognize the shortcomings of prototypes for more innovative designs, so that they can repeat the manufacture of better products (Darmalaksana, 2020; Steinke et al., 2018).

5. Test phase (testing) as feedback (feedback) on a previously designed prototype. Testing allows repeating the empathy process in a more desirable manner. Feedback from this phase will help improve the prototype, to ensure that the problem is handled appropriately (Darmalaksana, 2020; Steinke et al., 2018).

\section{Results and Discussion}

The results and discussion through the design thinking approach are below.

\section{Good Management Education}

Education is a process of improving, improving, changing knowledge, skills, abilities, attitudes and behavior of a person or group of people in an effort to educate human life through teaching and training guidance activities (Maunah, 2020). One of the education to form individual abilities is character education. Character cannot be inherited, but must be built and developed through a process (Gunawan, 2012). One of the characters that needs to be built is a frugal attitude. Thrift is an act that is clever in managing and spending money (Zalviana, 2017). 
Good financial management will familiarize individuals, especially children, to become individuals who have good financial literacy. Looking at the current phenomenon, most parents choose to surrender their children's education to tutoring academies, because they are busy working and do not have enough time to accompany their children to study (Fatimah, 2015). So it is very likely that saving education will also be handed over to a technological system which is considered more practical, especially in this sophisticated era.

The design thinking approach is expected to be able to find solutions to various problems that arise in terms of character education, including awareness of saving. This approach offers empathy, poses problems clearly, and seeks creative ideas (Steinke et al., 2018). Although parents provide direction on saving awareness, it also needs to be supported by creative and innovative technological sophistication. The main problem relates to financial management education (Fatimah, 2015) and utilizing technology sources as a means of support (Husaini, 2017). This study seeks to empathize with these problems to seek creative, innovative, and solutionbased ideas based on the inspiration of the Prophet's behavior.

\section{Hadiths Example in Saving}

Hadith is something that was relied on by the Prophet, which is in the form of words (qaul), deeds (af'al), statements (taqrir), and others (Soetari, 1994). Hadith of the Prophet Muhammad. agreed as the second source of Islam after al-Qur'an (Wahyudin Darmalaksana, 2017). Prophet SAW. himself is Rasul Saw. with personal ahlak al-Qur'an (Darmalaksana, 2020b). Hadith History of Bukhari: Prophet SAW. said:

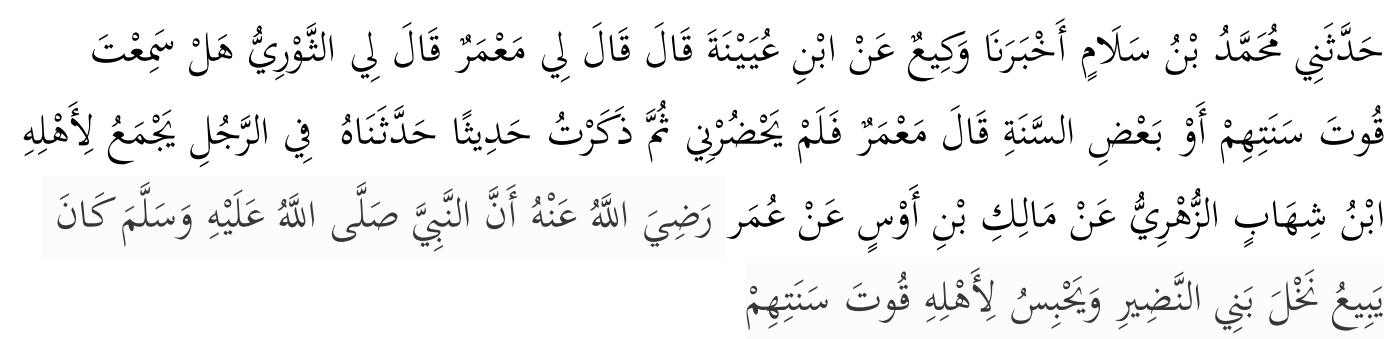

Meaning: Has told me Muhammad bin Salam has told us Waki 'from Ibn' Uyainah he said; Has told me Ma'mar has told me Ats Tsauri; "Have you ever heard of a man who collects food to supply for one year or after year for his family or?" Ma'mar said; He didn't answer. Then I also mentioned the hadith; Has told us Ibn Syihab Az Zuhri from Malik bin Aus from Umar radliallahu 'anhu, that the Holy Prophet. selling Bani Nadlir date palms and storing food for a year supply for his family "HR. Bukhari No.4938). 
The hadith has the following reinforcement:Hadits tersebut memiliki penguat sebagai berikut:

a) Musnad Ahmad 4304 which has the amplifiers of Sahih Bukhari 2158, 2798, 3727, 3728, 4505, 4938, Sahih Muslim 3284, 3285, 3286, Sunan Abu Daud 2248, Sunan Tirmidhi 1472, 3224, Sunan Ibnu Majah 2834, 2835, Musnad Ahmad 4890, 5262, 5325, and Musnad Darimi 2351 (carihadis.com).

b) Musnad Ahmad 5325 which has Sahih Bukhari 2158, 2798, 3727, 3728, 4505, 4938, Sahih Muslim 3284, 3285, 3286, Sunan Abu Daud 2248, Sunan Tirmidhi 1472, 3224, Sunan Ibnu Majah 2834, 2835, and Musnad Darimi 2351 (carihadis.com).

The words of the Prophet (PBUH), as stated above, are not directly related to saving activities. However, this hadith explicitly explains that the Prophet Muhammad. have been doing savings activities.

\section{Budget and Savings Planner}

Managing finances using the Budget and Savings Planner book system is a solution idea, a creative step by utilizing technology. This Budget and Savings Planner book can raise awareness of financial "literacy" especially in Indonesia. Indonesia, with its large population, is expected to be able to compete against the MEA (Masyarakat Ekonomi ASEAN) which is increasingly opening up opportunities. One way that can be done is to pay attention to finances by continuing to control personal financial expenses (Yushita, 2017). Buku The Budget and Savings Planner book is designed to help control finances.

The main target audience for the Budget and Savings Planner book is youth. According to Loudon and Bita (Agustia, 2013), adolescents are the most easily influenced by consumptive behavior (Eva Suminar, 2015). Consumptive actors find it difficult to control the desire to invest and save because of wrong financial management methods. Lack of self-control in spending income will lead to consumptive behavior (Herlindawati, 2015). So, the book Budget and Savings Planner is very suitable.

According to Malinda (2007) personal financial management is a process of achieving personal goals through structured and precise financial management. Giltman (2004) personal financial management is the art and science of managing the financial resources of individual units. According to Senduk (2004) there are five realms of approach in managing personal finances, namely: (1) buying and owning as many productive assets as possible; 2) regulating expenses; (3) be careful with debt; (4) set aside for the future; and (5) has protection.

The Budget and Saving Planner book helps to observe every movement of money by always recording it. Does the money go to the needs of food, fashion, entertainment, savings balances, or others. The end 
result, the Budget and Savings Planner Book can provide a comparison between expectations and reality (income and expenses). Finally, to get you started on the first steps to financial success, the Budget and Savings Planner Book can help make it happen.

\section{Conclusion}

Hadith of the Prophet Muhammad. provide inspiration in financial management according to design thinking through the empathize, define, ideate, prototype, and test phases. Prophet SAW. is an exemplary figure whose every action can be imitated. One of them is in managing finances. Through the example of the Prophet, the Budget and Savings Planner book can help save the country's economic growth to foster an attitude of fondness for saving. The design thinking approach encourages creative, innovative, and solution ideas. Through the design thinking Budget and Savings Planner, you have the potential to become an accountant yourself. This research is expected to be useful for all people who have difficulty managing finances. This study has the limitation of only discussing the Budget and Savings Planner so that further research is needed with an analysis of design thinking in other sectors. This study recommends continuous testing in order to find a more appropriate prototype.

\section{References}

Ardiana, M. (2017). Kontrol Diri, Pendidikan Pengelolaan Keuangan Keluarga, Pengetahuan Inklusi Keuangan Siswa Pengaruhnya terhadap Perilaku Menabung Siswa SMK Se Kota Kediri. Jurnal Ekonomi Pendidikan dan Kewirausahaan, 4(1), 59-75.

Agustia, D. (2013). Pengaruh faktor good corporate governance, free cash flow, dan leverage terhadap manajemen laba. Jurnal Akuntansi dan Keuangan, 15(1), 27-42.

Buana, D. R. (2020). Analisis perilaku masyarakat indonesia dalam menghadapi pandemi virus corona (Covid-19) dan kiat menjaga kesejahteraan jiwa. Salam: Jurnal Sosial dan Budaya Syar-i, 7(3), 217-226. carihadis.com. (n.d.). Retrieved November 12, 2020, from https:/ / carihadis.com/Musnad_Ahmad/4304.

carihadis.com. (n.d.). Retrieved November 12, 2020, from https:/ / carihadis.com/Musnad_Ahmad/5325.

Darmalaksana, W. (2020). Formula Penelitian Pengalaman Kelas Menulis. Kelas Menulis UIN Sunan Gunung Djati Bandung, 1.

Darmalaksana, W. (2020). Metode Penelitian Kualitatif Studi Pustaka dan Studi Lapangan. Pre-Print Digital Library UIN Sunan Gunung Djati Bandung, 2-6.

Darmalaksana, W. (2020). Template Penulisan Artikel Hadits dengan Pendekatan Design Thinking. Pre-Print Digital Library UIN Sunan 
Gunung Djati Bandung, 2-6.

Delyana Rahmawany Pulungan, L. K. (2019). Memotivasi Anak Usia Dini Menabung Demi Masa Depan. Proseding Seminar Nasional Kewirausahaan, 2-6.

Suminar, E., \& Meiyuntari, T. (2015). Konsep diri, konformitas dan perilaku konsumtif pada remaja. Persona: Jurnal Psikologi Indonesia, $4(02)$.

Fatimah, S. (2016). Motif 'Agar'dan Motif 'Karena'dalam Keputusan Orang Tua Memilih Lembaga Bimbingan Belajar (Studi Fenomenologi Alfred Schutz dalam Konteks Lembaga Bimbingan Belajar di Kabupaten Sukoharjo). SOSIALITAS; Jurnal Ilmiah Pend. Sos Ant, 5(2).

Gunawan, H. (2012). Pendidikan karakter. Bandung: Alfabeta

Herlindawati, D. (2017). Pengaruh kontrol diri, jenis kelamin, dan pendapatan terhadap pengelolaan keuangan pribadi mahasiswa pascasarjana Universitas Negeri Surabaya. Jurnal ekonomi pendidikan dan kewirausahaan, 3(2), 158-169.

Husaini, M. (2017). Pemanfaatan teknologi informasi dalam bidang pendidikan (e-education). MIKROTIK: Jurnal Manajemen Informatika, 2(1).

Keynes, J. M. (1935). The General Theory of Employment, Interest and Money. New York: Macmilan ST Martins Press.

Manggala, G. D. (2020). Analisis Perkembangan dan Proyeksi Perekonomian Indonesia dari Tahun 2014-2020 Setelah Adanya Pandemi Corona. Jurnal Ekonomi dan Bisnis (JEBSIS), 2(1), 1-5.

Maunah, B. (2020). Landasan Pendidikan. IAIN Tulungagung Institusional, 5-8.

Ardiana, M. (2017). Kontrol Diri, Pendidikan Pengelolaan Keuangan Keluarga, Pengetahuan Inklusi Keuangan Siswa Pengaruhnya terhadap Perilaku Menabung Siswa SMK Se Kota Kediri. Jurnal Ekonomi Pendidikan dan Kewirausahaan, 4(1), 59-75.

Shofiana, A. (2020). Implementasi Program Afiliasi Berbasis Virtual Team Dalam Umkm Sebagai Upaya Peningkatan Perekonomian Pada Masa Pandemi Covid-19 (Implementation Of Virtual Team-Based Affiliation Programs In Msmes As Efforts For Increasing The Economy In The Covid-19 Pandemic Period). Available at SSRN 3590822.

Soetari, E. (1994). Ilmu Hadits. Bandung: Amal Bakti Press.

Darmalaksana, W., Pahala, L., \& Soetari, E. (2017). Kontroversi Hadis sebagai Sumber Hukum Islam. Wawasan: Jurnal Ilmiah Agama dan Sosial Budaya, 2(2), 245-258.

Yushita, A. N. (2017). Pentingnya literasi keuangan bagi pengelolaan keuangan pribadi. Nominal: Barometer Riset Akuntansi dan Manajemen, 6(1), 11-26. 
Zalviana, R. (2017). Implementasi Sikap Hemat dalam Menggunakan Uang Saku pada Siswa di Madrasah Aliyah Negeri Kampar Tanjung Rambutan Kabupaten Kampar. Disertasi: UIN Syarif Kasim Riau.

\section{Acknowledgment}

Praise and gratitude never escape, I always pray to Allah SWT, because without Him I am nothing. To my parents who always support their children, and to the lecturers I admire and respect, Mr. Wahyudin Darmalaksana, M.Ag. As a lecturer in hadith and writing class activist at the Faculty of Ushuluddin. Without him, I don't think I would have known faster about the world of scientific writing in college. And do not forget, to our beloved friends in arms who always support each other. Thank you very much. 